\title{
Removal of benzotriazole by Photo-Fenton like process using nano zero-valent iron: response surface methodology with a Box-Behnken design
}

\author{
Mehdi Ahmadii, ${ }^{1,}$, Kurosh Rahmani ${ }^{3}$, Ayat Rahmani ${ }^{4}$, Hasan Rahmani ${ }^{1,2,5^{*}}$ \\ ${ }^{1}$ Environmental Technologies Research Center, Ahvaz Jundishapur University of Medical Sciences, Ahvaz, Iran \\ ${ }^{2}$ Ahvaz Jundishapur University of Medical Sciences, Department of Environmental Health Engineering, School of Health, \\ Ahvaz, Iran \\ ${ }^{3}$ Ardabil University of Medical Sciences, Department of Environmental Health Engineering, School of Health, Ardabil, Iran \\ ${ }^{4}$ Semnan University of Medical Sciences, Department of Environmental Health Engineering, School of Health, Semnan, Iran \\ ${ }^{5}$ Department of Environmental Health Engineering, Faculty of Health, Kashan University of Medical Sciences, Kashan, Iran \\ "Corresponding author: e-mail: hs.rahmani@yahoo.com
}

\begin{abstract}
In this paper, the removal of benzotriazole (BTA) was investigated by a Photo-Fenton process using nano zero valent iron (NZVI) and optimization by response surface methodology based on Box-Behnken method. Effect of operating parameters affecting removal efficiency such as $\mathrm{H}_{2} \mathrm{O}_{2}$, NZVI, and BTA concentrations as well as $\mathrm{pH}$ was studied. All the experiments were performed in the presence of ultraviolet radiation. Predicted levels and BTA removal were found to be in good agreement with the experimental levels $\left(\mathrm{R}^{2}=0.9500\right)$. The optimal parameters were determined at $60 \mathrm{~min}$ reaction time, $15 \mathrm{mg} \mathrm{L}^{-1} \mathrm{BTA}, 0.10 \mathrm{~g} \mathrm{~L}^{-1} \mathrm{NZVI}$, and $1.5 \mathrm{mmol} \mathrm{L}^{-1} \mathrm{H}_{2} \mathrm{O}_{2}$ for Photo-Fenton-like reaction. NZVI was characterized using X-ray diffraction (XRD), transmission electron microscope (TEM) images, and scanning electron microscope (SEM) analysis.
\end{abstract}

Keywords: benzotriazole, Photo-Fenton, Response surface methodology, Box-Behnken.

\section{INTRODUCTION}

In the last decade, benzotriazoles (BTAs) are extensively used in industrial products such as polymer stabilizers, airport deicers/anti-Icers, anti-corrosion chemicals, and even dishwashing detergents ${ }^{1}$. The annual production of BTA and its related derivatives has been reported to be in the range of 9000 tons/year worldwide ${ }^{2}$. In addition, the elimination of these compounds using conventional treatment processes appears to be poor that only $37-62 \%$ of BTA can be removed by conventional treatment processes $^{2,3}$. Also, due to their relative resistance to biodegradation, BTA is removed only the partial amounts of BTA in mechanical-biological treatment units ${ }^{3,4}$.

Advanced oxidation processes (AOPs) are alternative methods for the elimination of types of refractory compounds, principally due to the formation of hydroxyl radicals $\left(\mathrm{HO}^{*}\right)$. During advanced oxidation processes (AOPs), additional reactions occur in the presence of light that produce hydroxyl radicals or increase the production rate of hydroxyl radicals that are capable of rapidly oxidizing organic contaminants and converting them into harmless end-products, such as $\mathrm{H}_{2} \mathrm{O}$ and $\mathrm{CO}_{2}$, and inorganic ions from atoms ${ }^{5}$, which have been successfully used for the treatment of wastewaters from petrochemical $^{6,7}$, textile ${ }^{8,9}$, and pharmaceutical ${ }^{10,11}$ industries.

Previous studies have documented the removal/degradation of benzotriazole with advanced techniques in recent years (e.g., ferrate (VI) oxidation, ultrasonic, adsorption, photochemical degradation $)^{12-16}$.

In this study, Photo-Fenton-like process, which is based using nano zerovalent iron (NZVI), was used. In recent years, NZVI has been successfully used for the degradation of a wide range of organics ${ }^{17-20}$. Due to the lower operational cost and higher capability of iron nanoparticles in terms of reducing and stabilizing different types of pollutants, it is widely used in water and waste- water treatment ${ }^{21}$. The Fenton reaction is an advanced oxidation process (AOP) that underlines generation of highly reactive hydroxyl radicals $(\bullet \mathrm{OH})$ from a mixture of $\mathrm{Fe}^{2+}$ (ferrous ions) and $\mathrm{H}_{2} \mathrm{O}_{2}$ (hydrogen peroxide) ${ }^{22,23}$. In Fenton-like (based using nano zero valent iron) and Photo-Fenton-like process (UV/NZVI/ $\mathrm{H}_{2} \mathrm{O}_{2}$ ), ferrous and then ferric are formed. During a regular cycle, these ions increase the efficiency of the process ${ }^{24}$.

$\mathrm{Fe}^{0}+\mathrm{H}_{2} \mathrm{O}_{2} \rightarrow \mathrm{Fe}^{2+}+\mathrm{OH}^{\cdot}+\mathrm{OH}^{-}$

$\mathrm{Fe}^{2+}+\mathrm{H}_{2} \mathrm{O}_{2} \rightarrow \mathrm{Fe}^{3+}+\mathrm{OH}^{\cdot}+\mathrm{OH}^{-}$

$\mathrm{Fe}^{3+}+\mathrm{H}_{2} \mathrm{O}_{2} \rightarrow \mathrm{Fe}^{2+}+{ }^{\cdot} \mathrm{O}_{2} \mathrm{H}+\mathrm{H}^{+}$

$\mathrm{Fe}^{3+}+{ }^{\cdot} \mathrm{O}_{2} \mathrm{H}+\mathrm{H}^{+} \rightarrow \mathrm{Fe}^{2+}+\mathrm{H}_{2} \mathrm{O}_{2}$

$\mathrm{Fe}^{3+}+\mathrm{H}_{2} \mathrm{O} \rightarrow\left[\mathrm{Fe}(\mathrm{OH})^{2+}\right]+\mathrm{H}^{+}$

$\left[\mathrm{Fe}(\mathrm{OH})^{2+}\right]+\mathrm{h} v \rightarrow \mathrm{Fe}^{2+}+\mathrm{OH}^{\cdot}$

$\mathrm{H}_{2} \mathrm{O}_{2}+\mathrm{h} v \rightarrow 2 \mathrm{OH}^{*}$

Organic mater $+\mathrm{OH}^{\cdot} \rightarrow$ oxidized compound $+\mathrm{H}_{2} \mathrm{O}(8)$

In this study, we performed a lab-scaled experiment for removing BTA by Photo-Fenton-like process using NZVI and optimization by response surface methodology based on a Box-Behnken design.

Response surface methodology (RSM) is a statistical technique for designing experiments, building models, evaluating the effects of several factors and searching optimum conditions for desirable responses that not only time consuming, but also generally incapable of reaching the true optimum due to ignoring the interactions among variables. RSM can be used to optimize and understand the performance of complex systems. Using this technique, the interactions that may affect performance which can be evaluated by a limited number of planned experiments ${ }^{8}$. 


\section{MATERIAL AND METHODS}

\section{Reagents}

BTA (C6H5N3; CAS no. 95-14-7; purity 99\%), methanol (HPLC grade $\geq 99.9 \%$ ), sodium borohydride granular $(\geq 98 \%)$, iron (II) sulfate heptahydrate $\left(\mathrm{FeSO}_{4} \cdot 7 \mathrm{H}_{2} \mathrm{O}\right)$, sodium borohydride (NaBH4), sulfuric acid (95-97\%), ethanol (EtOH; purity $\geq 99.5 \%)$, hydrogen peroxide $(30 \%$ wt), and deoxygenated deionized water were obtained from Sigma Aldrich (Germany).

\section{Preparation and characterization of NZVI}

NZVI particles were synthesized by sodium boro hydride $\left(\mathrm{NaBH}_{4}\right)$ reduction method. First, the amount of $\mathrm{FeSO}_{4} \cdot 7 \mathrm{H}_{2} \mathrm{O}(10 \mathrm{~g})$ was added to $100 \mathrm{ml}$ of the aqueous solution of $30 \%$ ethanol and $70 \%$ deionized water. The $\mathrm{pH}$ value of the solution was adjusted to about 6.8 using $2 \mathrm{M}$ sodium hydroxide $(\mathrm{NaOH})(\mathrm{aq})$. Then, about $1.8 \mathrm{~g}$ of $\mathrm{NaBH}_{4}$ powder was added slowly to the mixture. The mixture was stirred for about $10 \mathrm{~min}$ at room temperature $\left(25^{\circ} \mathrm{C}\right)$ and then filtered through a $0.22 \mu \mathrm{m}$ filter. A solid residue which was formed was washed respectively, with pure ethanol and deoxygenated deionized water for three times and then kept in glass plate and kept in the dryer for drying $\left(150^{\circ} \mathrm{C}\right)$. The chemical reaction can be described by Eq. (1).

$\mathrm{Fe}\left(\mathrm{H}_{2} \mathrm{O}\right)_{6}{ }^{2+}+2 \mathrm{BH}_{4}^{-} \rightarrow \mathrm{Fe}^{0}+2 \mathrm{~B}(\mathrm{OH})_{3}+7 \mathrm{H}_{2} \uparrow$

Finally, the crystal structure as well as the size and the image of the nanoparticles were investigated by X-ray diffraction (XRD-6100, Shimadzu model), transmission electron microscopy (TEM, Philips model: CM-20), and scanning electron microscope (SEM) with voltage of 15 kV (Hitachi, Model: S-3400N), respectively.

The characteristic broad peak at $2 \theta$ of 45,55 , 65 and $83^{\circ}$ indicates that the zero valent iron is predominantly present in the sample. The SEM image of samples showed that the iron particles are in the form of Nano-spheres, which exist in contact with each other and form chains having diameters of 1-100 nm. The TEM images (1c) showed high resolution lattice fringes in the core, indicating the presence of a crystalline $\mathrm{Fe}^{0}$ phase. Images of nanosized zero-valent iron particles were prepared in the Faculty of Tehran University (Fig. 1).

\section{Experimental procedure}

All the Photo degradation experiments were performed in batch reactor system containing $250 \mathrm{~mL}$ of BTA, NZVI or $\mathrm{H}_{2} \mathrm{O}_{2}$. In the center of the reactor, a quartz sheath was placed, in which a radiation source was located using a UV lamp (Philips UV-C Lamp 6 watt) and the samples were poured in the reactor. The reactor was equipped with a stirrer. Different conditions of BTA dosage (15, 30 , and $\left.45 \mathrm{mg} \mathrm{L}^{-1}\right), \mathrm{H}_{2} \mathrm{O}_{2}$ dosage $(0.5,1$, and $1.5 \mathrm{mmol}$ $\left.\mathrm{L}^{-1}\right)$, and NZVI dosage $\left(0.05,0.1\right.$, and $\left.0.15 \mathrm{~g} \mathrm{~L}^{-1}\right)$ were tested. $\mathrm{pH}$ and UV radiation were considered constant during the experiments $(\mathrm{pH}=3$ and 6 watts of radiation). The $\mathrm{pH}$ of the solution was adjusted with $\mathrm{NaOH}$ and $\mathrm{H}_{2} \mathrm{SO}_{4}$ at room temperature $\left(25^{\circ} \mathrm{C}\right)$ and a $\mathrm{pH}$ meter was used for the measurement. The samples were placed in the reactor and stirred for a specific period (30 to $90 \mathrm{~min}$ ) at $200 \mathrm{rpm}$. Then, the iron nanoparticles were separated by a magnet and the samples were filtered prior to HPLC. The reduction in the chemical oxygen
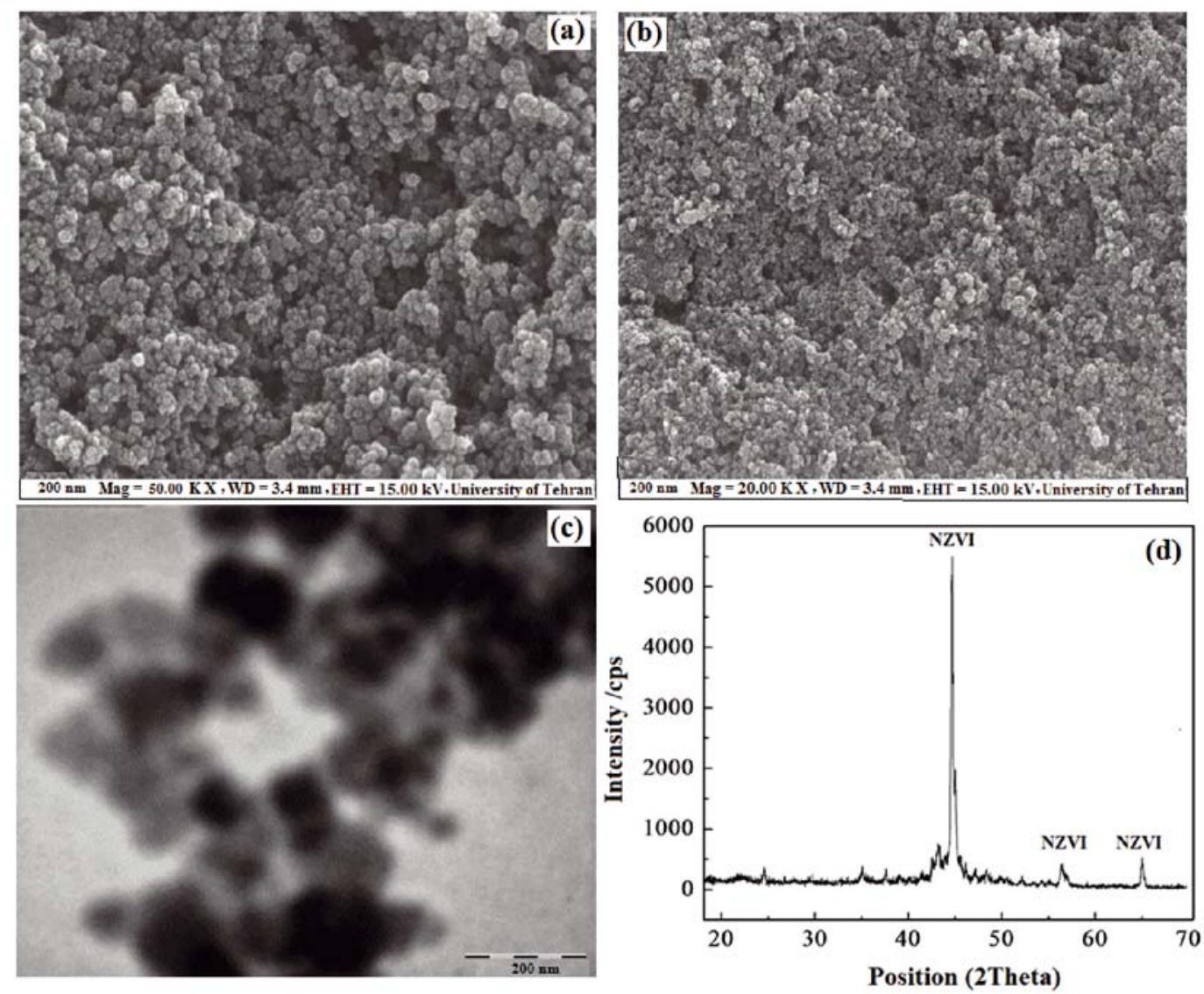

Figure 1. Characterization of NZVI particles: SEM (a and b), TEM (c), XRD (d) 
demand (COD) of BTA was determined for optimal conditions after the reaction time of $90 \mathrm{~min}$.

\section{Analytical methods}

After the centrifugation of the samples to remove NZVI particles during the reaction, BTA (BTA) was immediately analyzed by HPLC equipped with a UV detector (KNAUER Smart line UV Detector 2500) at $254 \mathrm{~nm}$ and a $\mathrm{C}_{18}$ column with an estimated detection limit of approximately $0.3 \mathrm{mg} / \mathrm{L}$. The mobile phase was a water $/$ methanol mixture $=30: 70(\mathrm{v} / \mathrm{v})$. The flow rate was kept at $0.2 \mathrm{~mL} \mathrm{~min}^{-1}$ and the injection volume was $10 \mu \mathrm{L}$ in all the samples. In the end, for data analysis, Design-Expert (Star-Ease Inc., MN, USA) statistical software was used.

The removal efficiency (R) of BTA was calculated by the following equation:

$\mathrm{R}=\left(\frac{\mathrm{C}_{\mathrm{o}}-\mathrm{C}_{\mathrm{e}}}{C_{0}}\right) \times 100$

Where $\mathrm{R}$ is the removal efficiency (\%), $\mathrm{C} 0$ the initial concentration of BTA $\left(\mathrm{mg} \mathrm{L}^{-1}\right)$, and Ce is the concentration in equilibrium of BTA $\left(\mathrm{mg} \mathrm{L}^{-1}\right)$.

\section{RSM model}

In this study, statistical techniques with the Box-Behnken design were used for the efficient removal of BTA and determining the relationship between these factors. In order for the response surface methodology (RSM) based on the Box-Behnken design, 29 experiments were conducted for four experimental factors at three levels. An RSM is appropriate when the optimal region for running the process is identified. The design used for the optimization and the observed responses for 29 experiments are given in Table 1. For the statistical calculations, the variables were coded to minimize, central, and maximum levels of each variable designated as -1 , 0 , and 1 , respectively. The effects of the initial concentration of BTA (15-45 mg L ${ }^{-1}$ ), NZVI concentration (0.05-0.15 g L $\left.{ }^{-1}\right), \mathrm{H}_{2} \mathrm{O}_{2}$ concentration $(0.5-1.5 \mathrm{mmol}$ $\mathrm{L}^{-1}$ ), and reaction time (30-90 $\left.\mathrm{min}\right)$.

The relationships between BTA removal and four independent variables (reaction time, BTA concentration, NZVI concentration, and $\mathrm{H}_{2} \mathrm{O}_{2}$ concentration. The levels and ranges of the studied process parameters (reaction time, BTA concentration, NZVI concentration, and $\mathrm{H}_{2} \mathrm{O}_{2}$ concentration) affecting the experiment are given in Table 2. The response (Y) could be related to the selected variables $(\mathrm{X} 1, \mathrm{X} 2, \mathrm{X} 3$, and $\mathrm{X} 4)$ by a second-order polynomial regression model as given in the following equation.

$\mathrm{y}=\beta_{0}+\sum_{j=1}^{k} \beta_{j} x_{j}+\sum_{j=1}^{k} \beta_{j j} x_{j}^{2}+\sum_{j=1}^{k} \sum_{i=1}^{i\langle j} \beta_{i j} x_{i} x_{j}+\varepsilon$

The independent, dependent, and experimental data are shown in Table 2 for every experiment (all experiments were repeated three times). The independent variables were applied reaction time (X1), initial BTA concentration (X2), NZVI concentration (X3), and $\mathrm{H}_{2} \mathrm{O}_{2}$ concentration (X4). The dependent variable or objective function was BTA removal efficiency. The independent variables were determined and coded as $\mathrm{Xi}$ using the following equation;

$\mathrm{X}_{i}=\left(\frac{\mathrm{x}_{\mathrm{i}}-\mathrm{x}_{0}}{\Delta \mathrm{x}_{\mathrm{i}}}\right)$

Where $\mathrm{X}_{\mathrm{i}}$ is the independent variable (dimensionless value), $x_{i}$ is the real value of the independent variable, $\mathrm{x}_{0}$ is the real value of the independent variable at the center point, and $\Delta \mathrm{X}$ is the step change values between low $(-1)$ and high $(+1)$ levels.

Table 1. Box-Behnken design matrix (BTA removal efficiency (\%) and predicted BTA removal (\%))

\begin{tabular}{|c|c|c|c|c|c|c|}
\hline Run & Time [min] & BTA [ppm] & $\mathrm{NZVI}[\mathrm{g} / \mathrm{L}]$ & $\mathrm{H}_{2} \mathrm{O}_{2 \text { [mmol/L] }}$ & $\begin{array}{c}\text { Response } \\
{[\%]}\end{array}$ & $\begin{array}{c}\text { Predicted } \\
{[\%]}\end{array}$ \\
\hline 1 & 0 & 1 & 1 & 0 & 39.200 & 43.3979 \\
\hline 2 & -1 & 0 & 0 & 1 & 42.000 & 46.3626 \\
\hline 3 & -1 & 0 & 1 & 0 & 32.230 & 32.6320 \\
\hline 4 & 0 & 1 & 0 & 1 & 53.480 & 50.6472 \\
\hline 5 & 0 & -1 & 0 & 1 & 73.400 & 74.2132 \\
\hline 6 & 1 & 1 & 0 & 0 & 48.254 & 50.3107 \\
\hline 7 & 0 & 0 & 1 & -1 & 23.000 & 22.3070 \\
\hline 8 & 0 & 0 & -1 & -1 & 24.000 & 29.7239 \\
\hline 9 & 0 & 0 & 1 & 1 & 65.560 & 59.3780 \\
\hline 10 & 1 & 0 & 0 & 1 & 68.560 & 72.1641 \\
\hline 11 & 1 & 0 & 0 & -1 & 34.900 & 32.4846 \\
\hline 12 & 1 & 0 & 1 & 0 & 49.345 & 48.5010 \\
\hline 13 & -1 & 0 & -1 & 0 & 33.370 & 32.7249 \\
\hline 14 & 0 & 1 & -1 & 0 & 42.890 & 41.7183 \\
\hline 15 & 0 & 0 & -1 & 1 & 65.867 & 66.1019 \\
\hline 16 & -1 & -1 & 0 & 0 & 39.400 & 36.8852 \\
\hline 17 & 0 & 0 & 0 & 0 & 47.000 & 47.2500 \\
\hline 18 & 0 & 0 & 0 & 0 & 47.300 & 47.2500 \\
\hline 19 & 1 & 0 & -1 & 0 & 64.440 & 62.5489 \\
\hline 20 & 0 & -1 & -1 & 0 & 62.140 & 59.8893 \\
\hline 21 & 1 & -1 & 0 & 0 & 60.630 & 60.1197 \\
\hline 22 & 0 & -1 & 0 & -1 & 22.000 & 23.3437 \\
\hline 23 & 0 & -1 & 1 & 0 & 40.950 & 44.0689 \\
\hline 24 & 0 & 1 & 0 & -1 & 30.370 & 28.0677 \\
\hline 25 & 0 & 0 & 0 & 0 & 47.750 & 47.2500 \\
\hline 26 & -1 & 1 & 0 & 0 & 27.800 & 27.8522 \\
\hline 27 & 0 & 0 & 0 & 0 & 47.200 & 47.2500 \\
\hline 28 & 0 & 0 & 0 & 0 & 47.000 & 47.2500 \\
\hline 29 & -1 & 0 & 0 & -1 & 14.250 & 12.5931 \\
\hline
\end{tabular}


Table 2. Coded and actual levels of the design factors

\begin{tabular}{|c|c|c|c|c|c|}
\hline Coded & Independent variable & $\begin{array}{c}\text { Low actual } \\
\text { value }\end{array}$ & $\begin{array}{c}\text { High actual } \\
\text { value }\end{array}$ & $\begin{array}{c}\text { Low coded } \\
\text { value }\end{array}$ & $\begin{array}{c}\text { High coded } \\
\text { value }\end{array}$ \\
\hline $\mathrm{X} 1$ & Reaction time [min] & 30 & 90 & -1 & +1 \\
\hline $\mathrm{X} 2$ & $\mathrm{BTA}$ concentration $[\mathrm{mg} / \mathrm{L}]$ & 15 & 45 & -1 & +1 \\
\hline $\mathrm{X} 3$ & $\mathrm{NZVI}$ concentration [g/L] & 0.05 & 0.15 & -1 & +1 \\
\hline $\mathrm{X} 4$ & $\mathrm{H}_{2} \mathrm{O}_{2}$ concentration $[\mathrm{mmol} / \mathrm{L}]$ & 0.5 & 1.5 & -1 & +1 \\
\hline
\end{tabular}

\section{RESULTS AND DISCUSSION}

\section{Modeling and statistical analysis}

The goodness of fit in the statistical model was examined by a determination coefficient $\left(\mathrm{R}^{2}\right)$. Also, the regression equation from the experimental results was obtained as follows:

$\mathrm{Y}_{\mathrm{BTA}} \%=44.79+11.42 \mathrm{X}_{1}-4.33 \mathrm{X}_{2}-3.54 \mathrm{X} 3+17.98 \mathrm{X} 4$ $+3.31 \mathrm{X}_{1}^{2}-0.1456 \mathrm{X}_{2}^{2}+0.1642 \mathrm{X}_{3}^{2}-3.036 \mathrm{X}_{4}^{2}-0.19 \mathrm{X}_{1} \mathrm{X}_{2}$ $+3.49 \mathrm{X}_{1} \mathrm{X}_{3}+1.48 \mathrm{X}_{1} \mathrm{X}_{4}+4.38 \mathrm{X}_{2} \mathrm{X}_{3}-8.21 \mathrm{X}_{2} \mathrm{X}_{4}+$ $0.17 \mathrm{X}_{3} \mathrm{X}_{4}$

In Eq. 5, Y is the percentage removal of BTA; and X1, $\mathrm{X} 2, \mathrm{X} 3$, and $\mathrm{X} 4$ are the corresponding coded variables of reaction time (X1), initial BTA concentration (X2), NZVI concentration (X3), and $\mathrm{H}_{2} \mathrm{O}_{2}$ concentration (X4), respectively.

The degradation efficiency of BTA with different advanced oxidation processes have been studied.

Comparison of advanced oxidation processes (AOPs) can be difficult due to physical and chemical differences in the fundamental processes used to produce $\mathrm{OH}^{\bullet}$ radicals. Summary of research published and comparison of different advanced oxidation processes for BTA degradation shown in Table 3.
Analysis of Variance (ANOVA) and adequacy of regression model

After determining the studied points, ANOVA values for the quadratic regression model obtained from the Box-Behnken employed in the optimization of BTA removal are shown in Table 4. The results indicated that the response equation proved to be suitable for the Box-Behnken experimented. The value of the correlation coefficient $\left(\mathrm{R}^{2}=0.9500\right)$ indicated that only $5 \%$ of the total variation was not explained by the empirical model. The low $\mathrm{p}$ value $(\mathrm{p}<0.0001)$ indicated that the model was considered to be statistically significant. Generally, the model's $\mathrm{P}$ values of greater than 0.1 are not significant, whereas the values of less than 0.05 indicate that the model terms are significant ${ }^{25}$.

Also, the model F-value of 34.17 implied that it was significant for the removal of the BTA. There was only a $0.01 \%$ chance that a model F-value with this size could occur due to noise. Values of Prob $>$ F less than 0.0500 indicate that the model terms are significant, since the $F$ model is 34.17 and has a low probability value (Prob $>F=0.0001)$. In this case $X 1, X 2, X 3$, $\mathrm{X} 4$, and $\mathrm{X} 2 \mathrm{X} 4$ are inefficient model terms. Values of greater than 0.1000 indicate the model terms are not significant. If there are many insignificant model terms (not counting those required to support hierarchy),

Table 3. Summary of research published and comparison of different advanced oxidation processes for BTA degradation

\begin{tabular}{|c|l|c|c|l|}
\hline- & Advanced oxidation process & Degradation [\%] & Time [min] & References \\
\hline 1 & BiOBr photocatalysis/ solar & 90 & 180 & Jian $\mathrm{Xu}^{39}$ \\
\hline 2 & $\mathrm{ZnFe} \mathrm{O}_{4}$ nanoparticles [PE-Fenton like] & 91.2 & 180 & $\mathrm{Junfeng} \mathrm{Wu}^{40}$ \\
\hline 3 & Photoperoxi-coagulation/ activated carbon fiber & 97.8 & 50 & Mehdi Ahmadi $^{41}$ \\
\hline 4 & $\mathrm{UV}$ irradiation [1070 mWs/cm ${ }_{2}$ ] & 90 & 120 & Lars J. Hem $^{12}$ \\
\hline 5 & $\mathrm{UV} / \mathrm{TiO}_{2}$ film & 89.8 & 180 & Yaobin Ding $^{42}$ \\
\hline 6 & $\mathrm{Cu} / \mathrm{MnO}_{2}[$ Fenton-like] & 89 & 60 & Yuting Zhang $^{43}$ \\
\hline 7 & $\mathrm{UV} / \mathrm{H}_{2} \mathrm{O}_{2}$ & 100 & 60 & Ewa Borowska $^{44}$ \\
\hline
\end{tabular}

Table 4. ANOVA for the regression model and respective model terms

\begin{tabular}{|c|c|c|c|c|c|c|}
\hline Source & Sum of Squares & $d f$ & $\begin{array}{l}\text { Mean } \\
\text { Square }\end{array}$ & $\begin{array}{c}\mathrm{F} \\
\text { Value }\end{array}$ & $\begin{array}{l}\text { p-value } \\
\text { Prob > F }\end{array}$ & \\
\hline Model & 6226.11 & 10 & 622.61 & 34.17 & $<0.0001$ & significant \\
\hline $\mathrm{X} 1-\mathrm{X} 1$ & 0.15 & 1 & 0.15 & $8.261 \mathrm{E}-003$ & 0.9286 & \\
\hline $\mathrm{X} 2-\mathrm{X} 2$ & 48.69 & 1 & 48.69 & 2.67 & 0.1195 & \\
\hline $\mathrm{X} 3-\mathrm{X3}$ & 8.73 & 1 & 8.73 & 0.48 & 0.4976 & \\
\hline $\mathrm{X} 4-\mathrm{X} 4$ & 76.56 & 1 & 76.56 & 4.20 & 0.0553 & \\
\hline $\mathrm{X} 1 \mathrm{X} 2$ & 269.29 & 1 & 269.29 & 14.78 & 0.0012 & \\
\hline $\mathrm{X} 1 \mathrm{X3}$ & 0.12 & 1 & 0.12 & $6.588 \mathrm{E}-003$ & 0.9362 & \\
\hline $\mathrm{X} 1 \mathrm{X} 4$ & 0.15 & 1 & 0.15 & $8.261 \mathrm{E}-003$ & 0.9286 & \\
\hline $\mathrm{X} 2 \times 3$ & 48.69 & 1 & 48.69 & 2.67 & 0.1195 & \\
\hline$\times 2 \times 4$ & 8.73 & 1 & 8.73 & 0.48 & 0.4976 & \\
\hline $\mathrm{X} 3 \times 4$ & 76.56 & 1 & 76.56 & 4.20 & 0.0553 & \\
\hline Residual & 328.02 & 18 & 18.22 & & & \\
\hline Lack of Fit & 327.64 & 14 & 23.40 & & & \\
\hline Pure Error & 0.38 & 4 & 0.095 & & & \\
\hline Cor Total & 6554.13 & 28 & & & & \\
\hline Std. Dev. & 4.27 & & R-Squared & 0.9500 & & \\
\hline Mean & 44.79 & & Adj R-Squared & 0.9221 & & \\
\hline C.V. $\%$ & 9.53 & & Pred R-Squared & 0.8444 & & \\
\hline PRESS & 1019.89 & & Adeq Precision & 23.653 & & \\
\hline
\end{tabular}


model reduction may improve the model. For adequacy of model, some coefficients can be calculated. For this purpose, R-squared, adjusted R-squared, predicted R-squared, the coefficient of variance (CV) and adequate precision were used. R-squared of 0.9500 indicated that most of the data variation can be described by this model. The adjusted R-squared value (0.9221) is very close to Rsquared implying high significance of the model. The predicted Rsquared should not have difference of more than 0.20 with adjusted R-squared. The predicted R-squared value (0.8444) almost dose significantly have difference. Adequate precision implies the signal to noise ratio. Its desired value is 4 or more. Adequate precision of 23.653 indicates an adequate signal. This model can be applied for navigation of the design space. The CV is an essential coefficient which indicates the reproducibility of the model if to be less than 10 . It was found that obtained $\mathrm{CV}$ value was 9.53 proposing model can be reproducible. Normal probability plot is a graphical

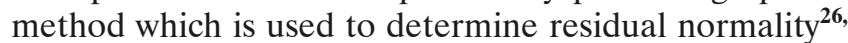
27. A normal probability plot of the residuals versus response (Y) is provided in Figure 2a. Graphical data on the plot located in a position close to a straight line showed that the model's sufficiency for removal by UV/ $\mathrm{NZVI} / \mathrm{H}_{2} \mathrm{O}_{2}$ process. Also, the experimental and predic- ted values for $\mathrm{Y}$ are shown in Figure $2 \mathrm{~b}$. The analysis and observations reiterated good correlation between the results taken by the experiments and the values predicted by the statistical model, which demonstrated the success of this model.

\section{Response surface plotting and optimization of the expe- rimental conditions}

\section{Interactive effect of reaction time and BTA concentration}

Three-dimensional representation of the response surface plot and two-dimensional contour plots were used to represent the obtained results. Figure 3 presents 3D plots demonstrating the effect of BTA concentration and reaction time on percentage BTA degradation under the predefined conditions specified by Design Expert software.

Figure 3 represents that, by increasing the reaction time and reduction of BTA concentrations, system performance was increased. In fact, with rising BTA concentrations, the ratio between hydroxyl radicals and BTA concentrations ( $\left.\mathrm{OH}^{*} / \mathrm{BTA}\right)$ would be reduced; more time is needed to remove BTA per unit of time. On the other hand, when the initial concentration of BTA is high, the degraded solution color is especially darkened.
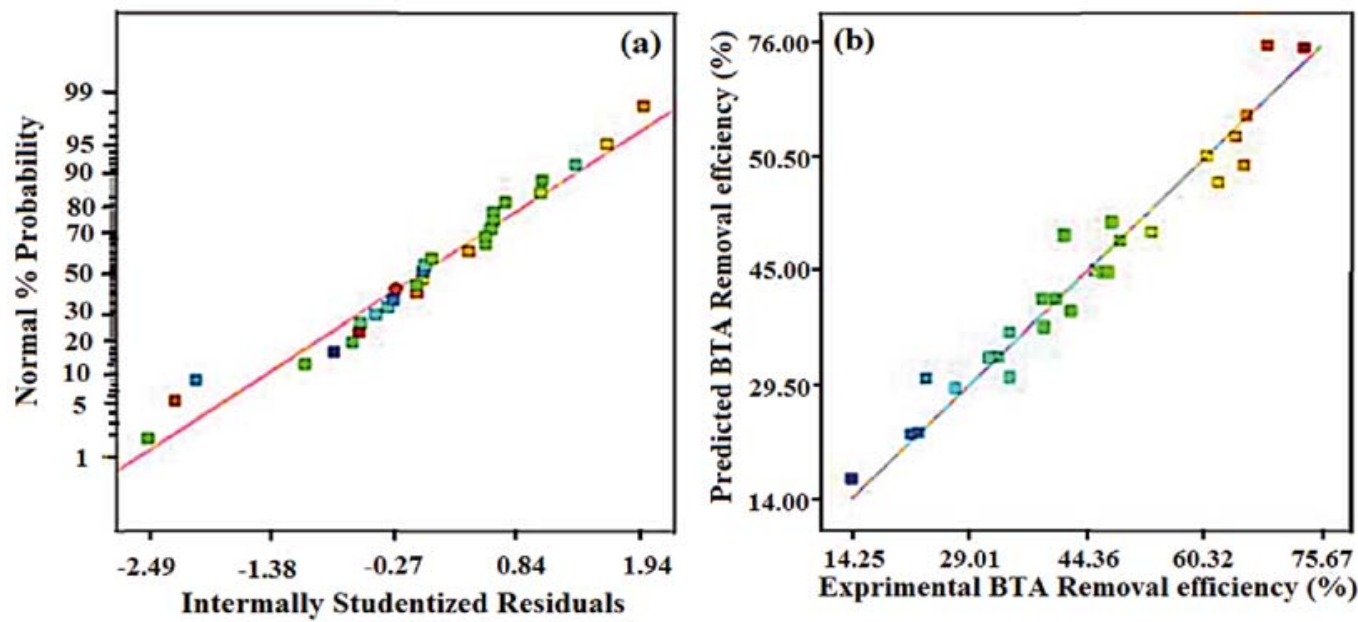

Figure 2. a) Normal plot of studentized residuals; b_) Predicted versus experimental BTA removal efficiency [\%]
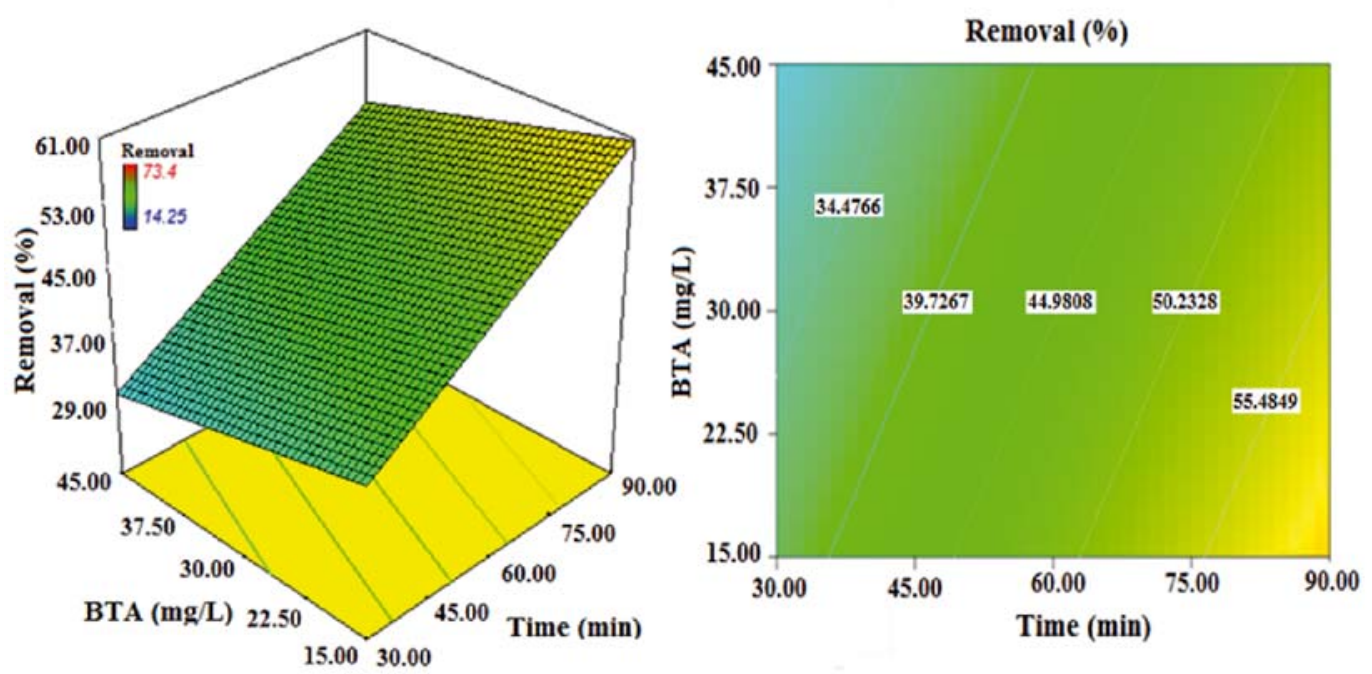

Figure 3. Response surface and contour plots showing the effect of reaction time (X1) (min), and BTA concentration (X2) [mg $\left.\mathrm{L}^{-1}\right]$ on BTA removal efficiency [\%] 
Thus, the transparency of solution becomes poor and the absorption of UV light provided for Reaction (7) is suppressed. The percentage of degradation can be increased to $73.4 \%$ when the time increased.

\section{Interactive effect of time and $\mathrm{H}_{2} \mathrm{O}_{2}$ concentration}

To understand the effect of each factor on the response variable, surface $2 \mathrm{D}$ contour plots and three-dimensional (3D) plots were made for the estimated value for maximal responses.

Figure 4 clearly shows that the degradation of BTA by Photo-Fenton like reactions gradually depended on the concentration of hydroxyl, which in turn depended on the concentration of hydrogen peroxide.

With an increase in the $\mathrm{H}_{2} \mathrm{O}_{2}$ concentration, the BTA degradation was increased overreaction time until it reached the optimum grade. Generally, it has been observed that the removal efficiency of pollutants increases with increasing doses of hydrogen peroxide ${ }^{\mathbf{1 0}}$. However, one of the negative effects of hydrogen peroxide is the scavenging of the generated hydroxyl radicals, which occurs at high amounts of hydrogen peroxide. Also, at alkaline $\mathrm{pH}$ (high $\mathrm{pH}$ values), $\mathrm{H}_{2} \mathrm{O}_{2}$ tends to react with hydroxyl radicals and lead to the formation of hydroperoxyl radicals $\left(\mathrm{HO}_{2}{ }^{\circ}\right)$ with weak oxidizing ability ${ }^{20}$. On the other hand, at $\mathrm{pH} 1-2$, due to $\mathrm{H}$ ions scavenging, the inhibition of the hydroxyl radical formation is most likely to happen. Previous studies have indicated that the ideal $\mathrm{pH}$ range to achieve high removal efficiency is in the $\mathrm{pH}$ range of $3-4^{28-30}$. In this study, $\mathrm{pH}=3$ was determined.

\section{Interactive effect of $\mathrm{NZVI}$ and $\mathrm{H}_{2} \mathrm{O}_{2}$ concentration}

Figure 5 shows the effect of $\mathrm{H}_{2} \mathrm{O}_{2}$ concentration and dose of the used nanoparticles on the degradation efficiency when the pollutant concentration was in the optimum range. The surface $2 \mathrm{D}$ contour plots and $3 \mathrm{D}$ response demonstrated that the degradation efficiency, increased with increasing the concentrations of both variables. The obtained results also represented that, by increasing the concentrations of hydrogen peroxide and zero valent iron nanoparticles and reducing the concentration of BTA, the removal efficiency increased. It should be noted that hydrogen peroxide in concentrations beyond the optimum concentration has free radical scavenger properties. In the Fenton-based processes, $\mathrm{Fe}^{0}$
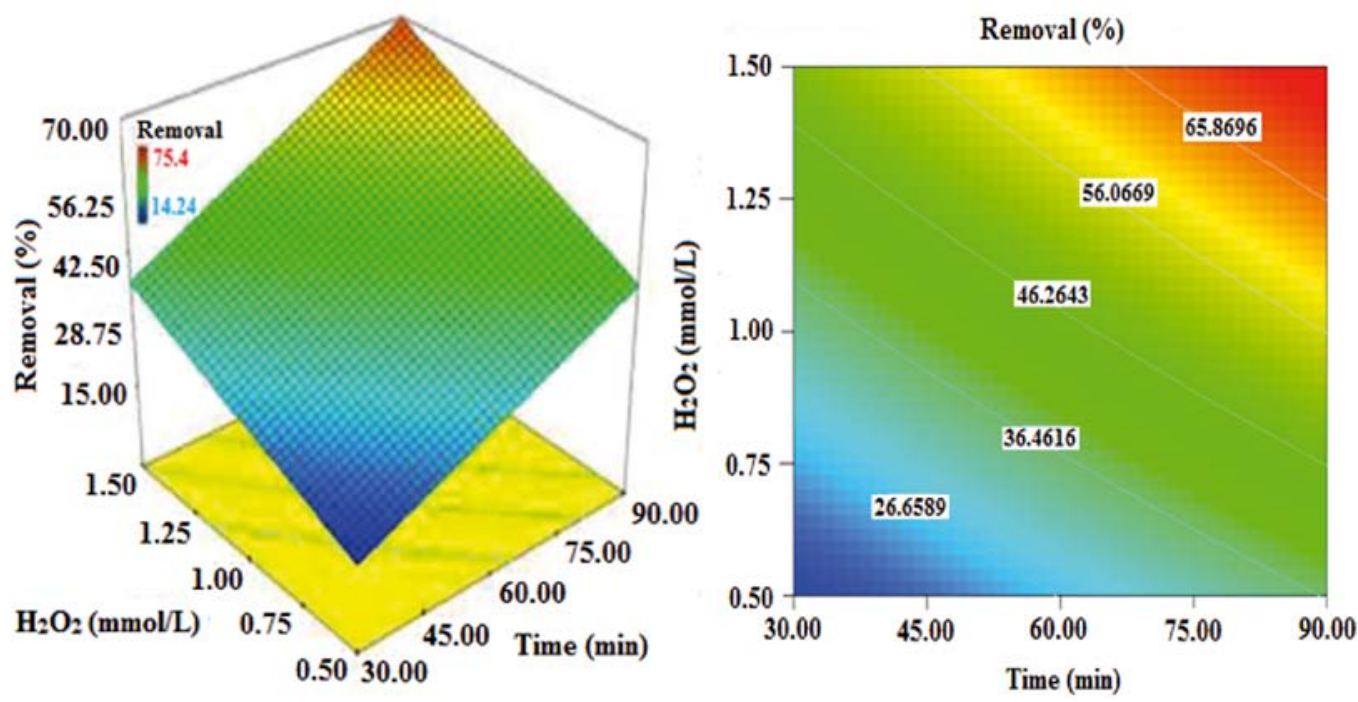

Figure 4. Response surface and contour plots showing the effect of reaction time (X1) [min], and $\mathrm{H}_{2} \mathrm{O}_{2}$ concentration $(\mathrm{X} 4)$ $\left[\mathrm{mM} \mathrm{L}^{-1}\right]$ on BTA removal efficiency [\%]
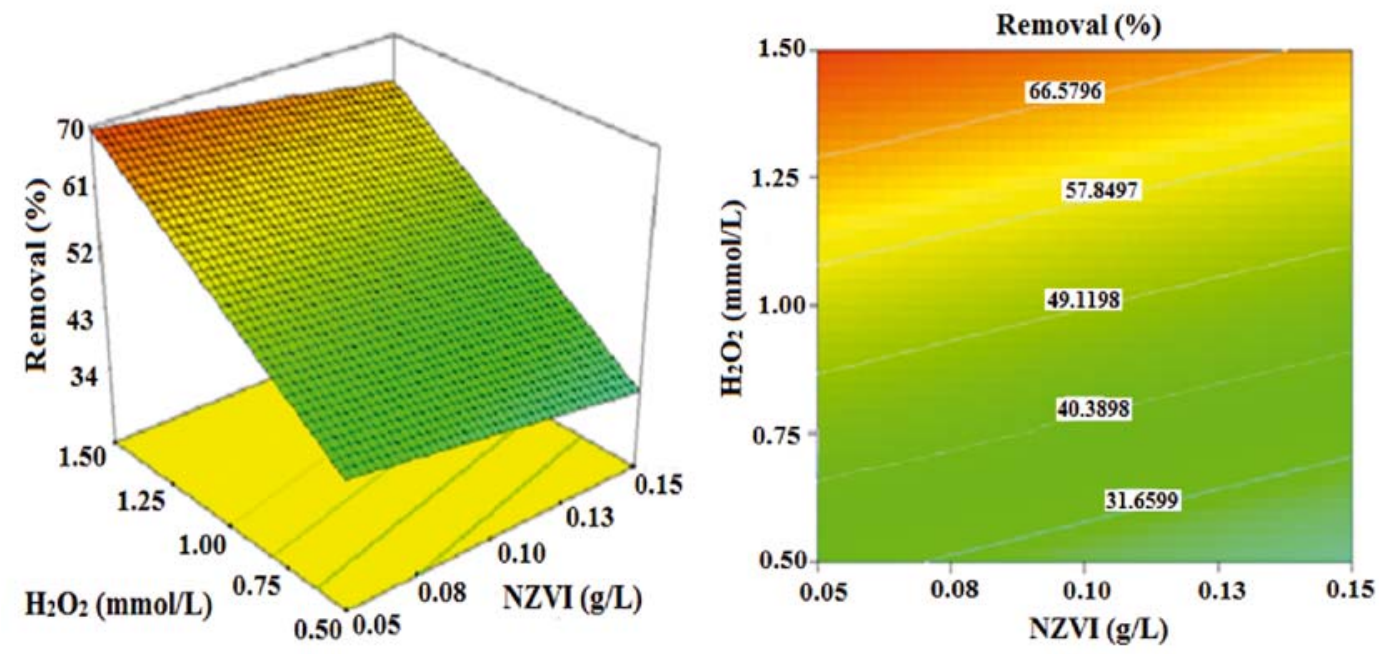

Figure 5. Response surface and contour plots showing the effect of NZVI concentration (X3) [g L $\mathrm{g}^{-1}$, and $\mathrm{H}_{2} \mathrm{O}_{2}$ concentration (X4) $\left[\mathrm{mM} \mathrm{L}^{-1}\right]$ on BTA removal efficiency [\%] 
usually undergoes certain side reactions, which results in the formation of less active or inactive species such as ferryl ion $\left(\mathrm{FeO}^{2+}\right)$ that can reduce oxidation efficiency ${ }^{23}$.

This unwanted behavior of ferrous ion is more important at low ferrous ion concentration and becomes less important as the concentration of ferrous ion increases with a ratio to oxidant concentration, because not all ferrous ions can be converted into ferryl ions and adequate ferrous ions will be available for the activation of oxidants at high ferrous ion concentration ${ }^{31}$. The effect of initial NZVI concentration is also important for the performance of the system. The pre-test showed that more than optimal amounts of iron nanoparticles led to lower productivity removal in the Photo-Fenton like process. Excessive use of nanoparticles resulted in staining and reducing the penetration of UV radiation. The ultraviolet radiation not only caused the formation of reactive radicals from oxidants, but also helped in the regeneration of ferrous ions ${ }^{32,33}$.

The mechanism through which the $\mathrm{H}_{2} \mathrm{O}_{2}$ / NZVI system produces oxidants involves the two-electron oxidation of NZVI followed by the Fenton-like reaction ${ }^{34-36}$. Initially, nano zero valent iron is oxidized through a two-electron transfer from the particle surface to $\mathrm{H}_{2} \mathrm{O}_{2}{ }^{25}, 26$.

\section{Interactive effect of NZVI and BTA concentration}

In this section, the effect of the BTA concentration $\left(15,30\right.$, and $\left.45 \mathrm{mg} \mathrm{L}^{-1}\right)$ and weight of NZVI (0.05. 0.1, and $0.15 \mathrm{~g} \mathrm{~L}^{-1}$ ) on the Photo-Fenton like process was examined (at $\mathrm{pH}$ of 3 , reaction time $90 \mathrm{~min}$ and hydrogen peroxide concentration of $1 \mathrm{mmol} / \mathrm{L}$ ).

The results in Table 3 showed that the maximum values for BTA removal (73.4\%) were obtained at the optimum level of BTA concentration $\left(15 \mathrm{mg} \mathrm{L}^{-1}\right)$ and with the optimum dosage of NZVI $\left(0.1 \mathrm{~g} \mathrm{~L}^{-1}\right)$. High dose of nanoparticles causes turbidity, which itself leads to prevent from the penetration and, consequently, reduced impact of UV radiation. Therefore, optimal dose should be used for these particles. Also, a reduction in efficiency in the dose of $0.05 \mathrm{~g} \mathrm{~L}^{-1}$ caused a reduction in the sources of free radical generation in terms of the interaction of different types of iron in the Photo-Fenton like system.

\section{Optimization of the experimental conditions}

In this study, we examined the effect of various parameters for BTA removal and COD reduction.

For the optimization of the process parameters, the point prediction option in the software was used. The optimized parameters obtained from statistical software and calculated from the regression equation were $\mathrm{H}_{2} \mathrm{O}_{2}$ dosage of $1.5 \mathrm{mmol} \mathrm{L}^{-1}$, NZVI dosage of $0.10 \mathrm{~g} \mathrm{~L}^{-1}$, a BTA dosage of $15 \mathrm{mg} \mathrm{L}^{-1}$, and $\mathrm{pH}$ of 3 . Also, Studies in recent years have shown that optimum conditions for Fenton and Fenton-like processes were determined as $\mathrm{pH}$ $3^{37,38}$. The corresponding COD and BTA reduction were $40 \%$ and $73.4 \%$, respectively. To confirm the reliability of the regression equations, duplicate confirmatory experiments were conducted under the optimum conditions.

The results were closely related to the results achieved from optimization analysis using desirability functions, clearly stipulating that Box-Behnken design along with desirability functions could be satisfactorily used to optimize the design for the experiments on the PhotoFenton like degradation of BTA.

\section{Real wastewater treatment}

In order to investigate the possibility of complete removal of pollutants, the results showed that in terms of the maximum concentration of nanoparticles $(0.15 \mathrm{~g} / \mathrm{L})$ and under the optimal concentration of hydrogen perox-

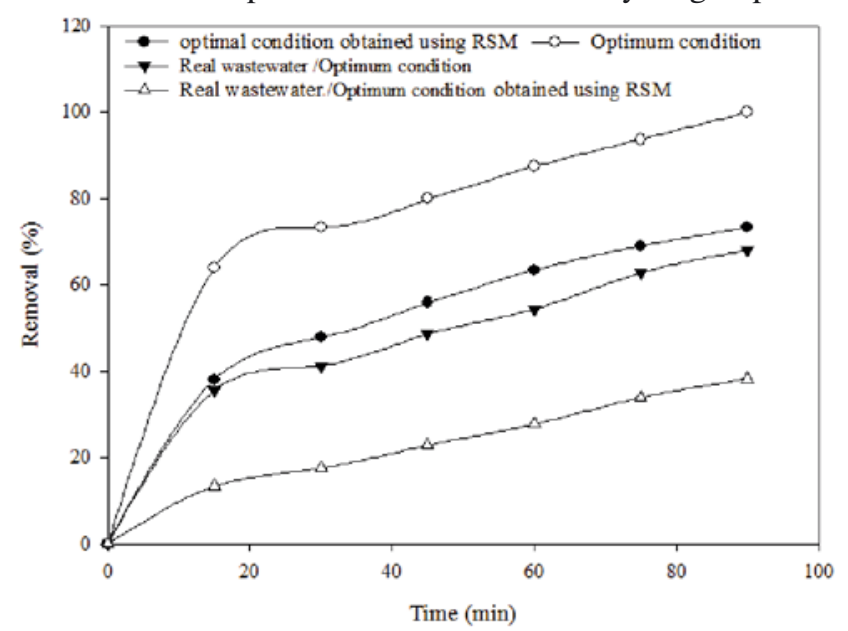

Figure 6. The actual wastewater versus the synthetic wastewater, regarding BTA removal by $\mathrm{UV} / \mathrm{nZVI} / \mathrm{H}_{2} \mathrm{O}_{2}$; optimal condition obtained using RSM (UV:6W/ nZVI:0.1 g/L and $\left.\mathrm{H}_{2} \mathrm{O}_{2}: 1.5 \mathrm{mmol} / \mathrm{L}\right)$, Optimum condition (UV:6W/nZVI:0.15 g/L and $\mathrm{H}_{2} \mathrm{O}_{2}: 1.5 \mathrm{mmol} / \mathrm{L}$ ), Real wastewater /Optimum condition and Real wastewater/ optimal condition obtained using RSM

Table 5. The characteristic of the selected industry effluent

\begin{tabular}{|l|c|}
\hline Parameter & Value \\
\hline Total COD [mg/L] & 1540 \\
\hline Soluble COD [mg/L] & 1320 \\
\hline $\mathrm{pH}$ & 6.8 \\
\hline TSS [mg/L] & 140 \\
\hline VSS [mg/L] & 103 \\
\hline
\end{tabular}

ide $(1.5 \mathrm{mmol} / \mathrm{L})$ the removal efficiency BTA and COD approaches to $100 \%$ and $70 \%$ after 90 min treatment.

Also in terms of the highest removal efficiency of the system (UV radiation $=6$ watt, nZVI concentration $=0.15 \mathrm{~g} / \mathrm{L}, \mathrm{H}_{2} \mathrm{O}_{2}$ dosage $=1.5 \mathrm{mmol} / \mathrm{L}$ and $\mathrm{pH}=3$ ), The process performance in real wastewater (Typical specifications for real wastewater are listed in Table 5) was evaluated and results showed that $68 \%$ and $43 \%$ was obtained for BTA and COD, respectively (Fig. 6). Results showed $\mathrm{pH} 3$ and $0.15 \mathrm{~g} / \mathrm{L} 1.5 \mathrm{mmol} / \mathrm{L}$ of nZVI and $\mathrm{H}_{2} \mathrm{O}_{2}$ concentration in contact with power 6 watt UV light are the most suitable condition for real wastewater treatment.

\section{CONCLUSIONS}

In this study, Photo-Fenton like process using NZVI was studied experimentally for BTA removal. Response surface methodology (RSM) based on Box-Behnken design was used to design the experiment and analyze four operating parameters of the experiment, including initial concentration of BTA $\left(15-5 \mathrm{mg} \mathrm{L}^{-1}\right)$, NZVI concentration (0.05-0.15 g L $\left.\mathrm{g}^{-1}\right), \mathrm{H}_{2} \mathrm{O}_{2}$ concentration $(0.5-1.5 \mathrm{mmol}$ $\mathrm{L}^{-1}$ ), and reaction time (30-90 min). BTA removal was enhanced by increasing $\mathrm{H}_{2} \mathrm{O}_{2}$ and NZVI concentrations 
up to certain levels, whereas further increases in NZVI concentrations resulted in negative effects due to $\mathrm{OH}$ radical scavenging at higher oxidant and reducing the influence of ultraviolet radiation due to the turbidity of high doses of nanoparticles. The optimum conditions were determined at the reaction time of $60 \mathrm{~min}, 15 \mathrm{mg}$ $\mathrm{L}^{-1}$ BTA, $0.10 \mathrm{~g} \mathrm{~L}^{-1}$ of NZVI, and $1.5 \mathrm{mmol} \mathrm{L} \mathrm{H}^{-1} \mathrm{H}_{2} \mathrm{O}_{2}$. Under optimal values of process parameters, the overall removal efficiency of $73.4 \%$ and $40 \%$ was achieved for BTA and COD, respectively. The present results implied that the response surface methodology (RSM) with a Box-Behnken can be used to identify the factors that are most effective in removing the BTA during a UV/ $\mathrm{NZVI} / \mathrm{H}_{2} \mathrm{O}_{2}$ process. Also Results showed $\mathrm{pH} 3$ and 0.15 $\mathrm{g} / \mathrm{L}$ of $\mathrm{nZVI}$ and $1.5 \mathrm{mmol} / \mathrm{L}$ of $\mathrm{H}_{2} \mathrm{O}_{2}$ concentration in contact with power 6 watt UV light are the most suitable condition for real wastewater treatment.

\section{ACKNOWLEDGMENTS}

The authors are grateful for the financial support of this project by the Research Council of Ahvaz Jundishapur University of Medical Sciences under grant number ETRC9319.

\section{LITERATURE CITED}

1. Castro, S., Davis, L.C. \& Erickson, L.E. (2005). Natural, cost-effective, and sustainable alternatives for treatment of aircraft deicing fluid waste. Environ. Prog. 24(1), 26-33. DOI: 10.1002/ep.10059.

2. Weiss, S.J., Jakobs, L.E. \& Reemtsma, T. (2006). Discharge of three benzotriazole corrosion inhibitors with municipal wastewater and improvements by membrane bioreactor treatment and ozonation. Environ. Sci. Technol. 40(23), 7193-7199. DOI: 10.1021/es061434i.

3. Giger, W., Schaffner, C. \& Kohler, H.-P.E. (2006). Benzotriazole and tolyltriazole as aquatic contaminants. 1. Input and occurrence in rivers and lakes. Environ. Sci. Technol. 40(23), 7186-7192. DOI: 10.1021/es061565j.

4. Alotaibi, M., et al. (2015). Benzotriazoles in the aquatic environment: a review of their occurrence, toxicity, degradation and analysis. Water, Air \& Soil Pollution. 226(7), 1-20. DOI: 10.1007/s11270-015-2469-4.

5. Oller, I., Malato, S. \& Sánchez-Pérez, J. (2011). Combination of advanced oxidation processes and biological treatments for wastewater decontamination-a review. Sci. Total Environ. 409(20), 4141-4166. DOI: 10.1016/j.scitotenv.2010.08.061.

6. Dimoglo, A., et al. (2004). Petrochemical wastewater treatment by means of clean electrochemical technologies. Clean Technol Envir. 6(4), 288-295. DOI: 10.1007/s10098-004-0248-9.

7. Chakinala, A.G. et al. (2009). Industrial wastewater treatment using hydrodynamic cavitation and heterogeneous advanced Fenton processing. Chem. Eng. J. 152(2), 498-502. DOI: $10.1016 /$ j.cej.2009.05.018.

8. Wang, Y., et al. (2014). Optimization of coagulation-flocculation process for papermaking-reconstituted tobacco slice wastewater treatment using response surface methodology. J. Ind. Eng. Chem. 20(2), 391-396. DOI: 10.1016/j.jiec.2013.04.033.

9. Nachiappan, S. \& Muthukumar, K. (2010). Intensification of textile effluent chemical oxygen demand reduction by innovative hybrid methods. Chem. Eng. J. 163(3), 344-354. DOI: 10.1016/j.cej.2010.08.013.

10. Tekin, H., et al. (2006). Use of Fenton oxidation to improve the biodegradability of a pharmaceutical wastewater. J. Hazard. Mater. 136(2), 258-265. DOI: 10.1016/j.jhazmat.2005.12.012.

11. Farzadkia, M., et al. (2014). Investigation of photocatalytic degradation of clindamycin antibiotic by using nano- $\mathrm{ZnO}$ catalysts. Korean J. Chem. Eng. 31(11), 2014-2019. DOI: 10.1007/s11814-014-0119-y.

12. Hem, L.J., et al. (2003). Photochemical degradation of benzotriazole. J. Environ. Sci. Health, Part A. 38(3), 471-481. DOI: 10.1081/ESE-120016907.

13. Xu, B., et al. (2010). Benzotriazole removal from water by $\mathrm{Zn}-\mathrm{Al}-\mathrm{O}$ binary metal oxide adsorbent: Behavior, kinetics and mechanism. J. Hazard Mater. 184(1), 147-155. DOI: 10.1016/j.jhazmat.2010.08.017.

14. Yang, B., et al. (2011). Kinetics modeling and reaction mechanism of ferrate (VI) oxidation of benzotriazoles. Water Res. 45(6), 2261-2269. DOI: 10.1016/j.watres.2011.01.022.

15. Zúñiga-Benítez, H., Soltan, J. \& Peñuela, G. (2014). Ultrasonic degradation of 1-H-benzotriazole in water. Water Sci. Technol. 70(1), 152-159. DOI: 10.2166/wst.2014.210.

16. Bahnmüller, S., et al. (2015). Degradation rates of benzotriazoles and benzothiazoles under UV-C irradiation and the advanced oxidation process UV/H 2 O 2. Water Res. 74, 143-154. DOI: 10.1016/j.watres.2014.12.039.

17. Crane, R. \& Scott, T. (2012). Nanoscale zero-valent iron: future prospects for an emerging water treatment technology. J. Hazard. Mater. 211, 112-125. DOI: 10.1016/j. jhazmat.2011.11.073.

18. Fu, F., Dionysiou, D.D. \& Liu, H. (2014). The use of zero-valent iron for groundwater remediation and wastewater treatment: a review. J. Hazard. Mater. 267, 194-205. DOI: 10.1016/j.jhazmat.2013.12.062.

19. Chen, H., et al. (2016). Facile synthesis of graphene nano zero-valent iron composites and their efficient removal of trichloronitromethane from drinking water. Chemosphere. 146, 32-39. DOI: 10.1016/j.chemosphere.2015.11.095.

20. Zhang, J., et al. (2011). 3-aminopropyltriethoxysilane functionalized nanoscale zero-valent iron for the removal of dyes from aqueous solution. Pol. J. Chem. Technol. 13(2), 35-39. DOI: 10.2478/v10026-011-0021-x.

21. Pradhan, A.A. \& Gogate, P.R. (2010). Degradation of p-nitrophenol using acoustic cavitation and Fenton chemistry. J. Hazard. Mater. 173(1), 517-522. DOI: 10.1016/j. jhazmat.2009.08.115.

22. Wang, S. (2008). A Comparative study of Fenton and Fenton-like reaction kinetics in decolourisation of wastewater. Dyes Pigm. 76(3), 714-720. DOI: 10.1016/j.dyepig.2007.01.012.

23. Jiang, C., et al. (2010). A new insight into Fenton and Fenton-like processes for water treatment. J. Hazard. Mater. 174(1-3), 813-817. DOI: 10.1016/j.jhazmat.2009.09.125.

24. Weng, C.H., et al. (2013). Decolourization of direct blue 15 by Fenton/ultrasonic process using a zero-valent iron aggregate catalyst. Ultrason. Sonochem. 20(3), 970-977. DOI: 10.1016/j.ultsonch.2012.09.014.

25. O'Rourke, N., Psych, R. \& Hatcher, L. (2013). A step-by-step approach to using $S A S$ for factor analysis and structural equation modeling. Sas Institute.

26. Tripathi, P., Srivastava, V.C. \& Kumar, A. (2009). Optimization of an azo dye batch adsorption parameters using Box-Behnken design. Desalination 249(3), 1273-1279. DOI: 10.1016/j.desal.2009.03.010.

27. Khataee, A.R., Zarei, M. \& Moradkhannejhad, L. (2010). Application of response surface methodology for optimization of azo dye removal by oxalate catalyzed photoelectro-Fenton process using carbon nanotube-PTFE cathode. Desalination 258(1-3), 112-119. DOI: 10.1016/j.desal.2010.03.028.

28. Rahmani, H., et al. (2014). Tinidazole Removal from Aqueous Solution by Sonolysis in the Presence of Hydrogen Peroxide. Bull. Environ. Contam. Toxicol. 92(3), 341-346. DOI: 10.1007/s00128-013-1193-2.

29. Lucas, M.S. \& Peres, J.A. (2006). Decolorization of the azo dye Reactive Black 5 by Fenton and photo-Fenton oxidation. Dyes Pigm. 71(3), 236-244. DOI: 10.1016/j.dyepig.2005.07.007. 
30. Ahmadi Moghaddam, M., et al. (2010). Degradation of 2, 4-dinitrophenol by photo fenton process. Asian J. Chem. 22(2), 1009-1016.

31. Chan, K. \& Chu, W. (2003). Modeling the reaction kinetics of Fenton's process on the removal of atrazine. Chemosphere.51(4), 305-311. DOI: 10.1016/S0045-6535(02)00812-3.

32. Hermosilla, D., Cortijo, M. \& Huang, C. (2009). The role of iron on the degradation and mineralization of organic compounds using conventional Fenton and photo-Fenton processes. Chem. Eng. J. 155(3), 637-646. DOI: 10.1016/j. cej.2009.08.020.

33. Cavalcante, R.P., et al. (2013). Application of Fenton, photo-Fenton, solar photo-Fenton, and UV/H2O2 to degradation of the antineoplastic agent mitoxantrone and toxicological evaluation. Environ. Sci. Poll. Res. 20(4), 2352-2361. DOI: 10.1007/s11356-012-1110-y.

34. Keenan, C.R. \& Sedlak, D.L. (2008). Factors affecting the yield of oxidants from the reaction of nanoparticulate zero-valent iron and oxygen. Environ. Sci. Technol. 42(4), 1262-1267. DOI: 10.1021/es7025664.

35. Lee, C., Keenan, C.R. \& Sedlak, D.L. (2008). Polyoxometalate-enhanced oxidation of organic compounds by nanoparticulate zero-valent iron and ferrous ion in the presence of oxygen. Environ. Sci. Technol. 42(13), 4921-4926. DOI.

36. Lee, C. \& Sedlak, D.L. (2008). Enhanced formation of oxidants from bimetallic nickel- iron nanoparticles in the presence of oxygen. Environ. Sci. Technol. 42(22), 8528-8533. DOI: 10.1021/es801947h.

37. Mert, B.K., et al. (2010). Pre-treatment studies on olive oil mill effluent using physicochemical, Fenton and Fenton-like oxidations processes. J. Hazard. Mater. 174(1), 122-128. DOI: 10.1016/j.jhazmat.2009.09.025.

38. Babuponnusami, A. \& Muthukumar, K. (2014). A review on Fenton and improvements to the Fenton process for wastewater treatment. J. Environ. Chem. Engineer. 2(1), 557-572. DOI: $10.1016 /$ j.jece.2013.10.011.

39. Xu, J., et al. (2013). Removal of benzotriazole from solution by $\mathrm{BiOBr}$ photocatalysis under simulated solar irradiation. Chem. Eng. J. 221, 230-237. DOI: 10.1016/j.cej.2013.01.081.

40. Wu, J., et al. (2013). Removal of benzotriazole by heterogeneous photoelectro-Fenton like process using $\mathrm{ZnFe} 2$ O 4 nanoparticles as catalyst. J. Environ. Sci. 25(4), 801-807. DOI: 10.1016/S1001-0742(12)60117-X.

41. Ahmadi, M., Ghanbari, F. \& Madihi-Bidgoli, S. (2016). Photoperoxi-coagulation using activated carbon fiber cathode as an efficient method for benzotriazole removal from aqueous solutions: Modeling, optimization and mechanism. J. Photochem. Photobiol. A: Chemistry 322, 85-94. DOI: 10.1016/j. jphotochem.2016.02.025.

42. Ding, Y., et al. (2010). Photoelectrochemical activity of liquid phase deposited TiO 2 film for degradation of benzotriazole. J. Hazard. Mater. 175(1), 96-103. DOI: 10.1016/j. jhazmat.2009.09.037.

43. Zhang, Y., et al. (2016). Degradation of benzotriazole by a novel Fenton-like reaction with mesoporous $\mathrm{Cu} / \mathrm{MnO} 2$ : $\mathrm{Com}-$ bination of adsorption and catalysis oxidation. Appl. Catal. B: Environmental 199, 447-457. DOI: 10.1016/j.apcatb.2016.06.003.

44. Borowska, E., Felis, E. \& Kalka, J. (2016). Oxidation of benzotriazole and benzothiazole in photochemical processes: Kinetics and formation of transformation products. Chem. Eng. J. 304, 852-863. DOI: 10.1016/j.cej.2016.06.123. 